\section{Why Work with Undergraduate Researchers? Differences in Research Advisors' Motivations and Outcomes by Career Stage}

\author{
Charles N. Hayward,* Sandra L. Laursen, and Heather Thiry
}

Ethnography \& Evaluation Research, University of Colorado Boulder, Boulder, CO 80309-0580

\begin{abstract}
Undergraduate research is often hailed as a solution to increasing the number and quality of science, technology, engineering, and mathematics graduates needed to fill the hightech jobs of the future. Student benefits of research are well documented but the emerging literature on advisors' perspectives is incomplete: only a few studies have included the graduate students and postdocs who often serve as research advisors, and not much is known about why research advisors choose to work with undergraduate researchers. We report the motivations for advising undergraduate researchers, and the related costs and benefits of doing so, from 30 interviews with research advisors at various career stages. Many advisors stated intrinsic motivations, but a small group of early-career advisors expressed only instrumental motivations. We explore what this means for how advisors work with student researchers, the benefits students may or may not gain from the experience, and the implications for training and retaining research advisors who can provide high-quality research experiences for undergraduate students.
\end{abstract}

\section{INTRODUCTION}

The benefits of undergraduate research for students are well documented and include personal and professional gains, research skills, career clarification, enhanced preparation for careers and graduate school, and the ability to think and work like a scientist (Osborn and Karukstis, 2009; Laursen et al., 2010; Lopatto and Tobias, 2010; Linn et al., 2015). Other researchers have linked participation in undergraduate research with intention to continue in science, technology, engineering, and mathematics (STEM)-related graduate programs, particularly for students otherwise underrepresented in these fields (National Academy of Sciences, National Academy of Engineering, and Institute of Medicine, 2011; Eagan et al., 2013). One study even reported that undergraduate researchers reported increased productivity and satisfaction when they advanced and in turn became advisors for undergraduate research projects during their graduate studies (Lunsford, 2012).

Because of these benefits, undergraduate research opportunities have been, and continue to be, an important aspect of federal plans to help improve STEM education and train qualified students for the STEM workforce of the future (Boyer Commission on Educating Undergraduates in the Research University, 1998; National Science and Technology Council, 2013). While these plans advocate for increasing access to undergraduate research opportunities, this goal presents challenges. Either we must find ways to increase the number of students each research advisor can sponsor, or we must increase the number of advisors who work with undergraduates in apprentice-style research. Increasing the number of students each advisor works with presents challenges, as advisors may be pressured to take on less-prepared students who require more time to train or to take on too many students to provide meaningful
Erin L. Dolan, Monitoring Editor Submitted July 21, 2016; Revised December 12, 2016; Accepted December 12, 2016 CBE Life Sci Educ March 1, 2017 16:ar13 DOI:10.1187/cbe.16-07-0229

*Address correspondence to: Charles N. Hayward (chuck.hayward@colorado.edu).

() 2017 C. N. Hayward et al. CBE-Life Sciences Education () 2017 The American Society for Cell Biology. This article is distributed by The American Society for Cell Biology under license from the author(s). It is available to the public under an Attribution-Noncommercial-Share Alike 3.0 Unported Creative Commons License (http://creativecommons.org/licenses/ by-nc-sa/3.0).

"ASCB®" and "The American Society for Cell Biology $\AA^{\circ}$ are registered trademarks of The American Society for Cell Biology. 
personal interactions with all of them (Laursen et al., 2010). Course-based research experiences are another possible way to increase the number of students working with each research advisor (Bangera and Brownell, 2014; Corwin-Auchincloss et al., 2014; National Academies of Sciences, Engineering, and Medicine, 2015). This approach is currently being tested and studied.

The other tactic for increasing the number of potential research advisors who engage undergraduates in apprentice-style research experiences presents its own challenges. Proper training may be necessary to ensure that new advisors are prepared to provide high-quality research experiences for undergraduates (Pfund et al., 2006). In fact, in a large-scale survey of both advisors and students involved in research experiences, students' most commonly suggested improvement was more frequent and better quality guidance from their advisors (Russell et al., 2007).

Another challenge of increasing the number of advisors is motivation, or whether or not potential advisors want to work with undergraduate researchers. Morales et al. (2016) offer a model of advisor motivation that takes into account five types of influences: 1) expected costs and benefits, 2) previous mentoring experience, 3) situational factors, 4) demographic factors, and 5) dispositional factors.

There is some research available on how each of these factors affects advisors' motivations. Benefits for advisors are associated with higher participation in undergraduate research and include advancing the advisor's own research agenda (Adedokun et al., 2010; Laursen et al., 2010), while the time for training undergraduate researchers is a cost that deters advisors (Adedokun et al., 2010; Baker et al., 2015). Situational factors are also influential. Some advisors are deterred by institutional practices that do not formally recognize and reward engagement in undergraduate research in their tenure and evaluation processes; conversely, available funding to support undergraduate researchers can help encourage advisors to participate (Laursen et al., 2010; Eagan et al., 2011; Baker et al., 2015).

In addition to the influence of situational factors and anticipated costs and benefits, both individual and institutional demographics are associated with varying participation rates of research advisors. Among individual demographic factors, faculty of color (Webber et al. 2013), midcareer faculty (Morales et al. 2016), and faculty in the life sciences (Eagan et al., 2011) are more likely to advise undergraduate researchers. Among institutional variables, Eagan et al. (2011) report that faculty members were more likely to engage undergraduates in their research if they worked at liberal arts colleges, historically Black colleges or universities, or more selective schools. Baker et al. (2015) reported that faculty at one liberal arts institution were motivated to engage in undergraduate research because doing so aligned with the goals of a liberal arts education; at another institution, the strategic plan included goals that motivated faculty to participate. Yet, at many institutions, faculty often report feeling a tension between focusing on teaching versus research (Brownell and Tanner, 2012). Even at teaching-focused undergraduate institutions, publications may be important for tenure and promotion, and the slower pace of research involving undergraduates can cause publication rates to dip (Laursen et al., 2010).
The fifth type of influence, dispositional factors, is still relatively unexplored. Morales et al. (2016) identified only one dispositional factor in their model, "organizational citizenship behavior," which they described as exerting more effort than is required by one's formal role. They measured it using three survey items. They asked respondents to rate how strongly they agreed or disagreed with statements about increasing diversity through undergraduate research, enjoying teaching students about research, and helping prepare students for graduate studies. Moreover, only one of these items, "I value the opportunity to increase diversity in the academy through mentorship of underrepresented minority undergraduates," was significantly correlated with participation in undergraduate research advising. There is still much to learn about undergraduate research advisors' motivations, especially in the area of dispositional factors.

In this paper, we expand this modest literature to address research advisors' motivations to work with undergraduates in a research-focused institution. The present study builds on our prior work about students' perspectives and outcomes from undergraduate research (Thiry and Laursen, 2011). In that study, students cited important types of professional, intellectual, and personal support that their advisors provided as they interacted over the course of the research project. To examine the other side of these interactions, we conducted a complementary interview study designed to explore advisors' perspectives about their students' experiences and outcomes (Hayward et al., 2013). While we began with a focus on advisors' observations about their students, in conducting and analyzing these interviews, we found that advisors' motivations for engaging in undergraduate research emerged as important in their own right. In this qualitative analysis, we explore the phenomenon of advisor motivation, including some motivating factors that are not currently addressed in the literature. We use interview data to examine the range of motivations that novice and experienced research advisors reported, identify possible relationships between advisors' career stages and motivations, and suggest ways in which advisor motivations may shift over the course of an academic career.

\section{Types of Motivation}

Because motivations emerged as a central topic in our interview data, we start by offering some insight from the available research literature on motivations, which we then use to interpret and frame the discussion of our results. Previous research on motivation in various fields has found that the type of motivation affects outcomes. Motivations generally fall into two main types. Somebody who is intrinsically motivated to engage in an activity will do so even in the absence of external reward (Ryan and Deci, 2000). Extrinsically motivated individuals, on the other hand, are driven by outcomes and forces separate from the activity itself, such as rewards, recognition, or social pressure (Ryan and Deci, 2000). The names and definitions of different types of motivations vary slightly from source to source and field to field. Some researchers have argued for different terms because intrinsic and extrinsic are ambiguous about whether they refer to the person or the activity and because intrinsic seems to imply an inherent pleasure in the activity (Wrzesniewski et al., 2014). We choose to use intrinsic to refer to motivations inherent to 
the activity itself and instrumental to describe motivations that serve as a means to an end that is outside of the activity of research advising. These choices help to alleviate some of the common misconceptions and are consistent with the labeling in the few other available studies that discuss research advisor motivations (e.g., Dolan and Johnson, 2009; Prunuske et al., 2013).

When people with different motivations are compared, those with intrinsic motivations tend to have better performance and outcomes in various settings, including high school completion (Vallerand et al., 1997), workplace performance (Grant et al., 2011), and retention and promotion in the military (Wrzesniewski et al., 2014). Moreover, offering instrumental motivations for an activity that one already finds intrinsically motivating can be detrimental, rather than additive. Deci and Ryan's (1985) seminal work includes a review of multiple examples in laboratory settings in which introducing instrumental motivations (e.g., a reward) for doing activities that were already intrinsically motivating resulted in decreased enjoyment of those activities. There are also real-life, nonlaboratory examples of the detrimental effects of mixed motivations. Among West Point cadets, those who expressed both intrinsic and instrumental motivations tended to fall midrange on long-term outcome measures such as graduation rates, early promotion, and retention beyond mandatory service periods; they underperformed cadets with mainly intrinsic motivations but surpassed those with mainly instrumental motivations (Wrzesniewski et al., 2014). In another study, when volunteers held multiple motivations, they found the act of volunteering to be more stressful, more costly, less fulfilling, and less satisfying than volunteers who expressed only a single motivation (Kiviniemi et al., 2002), suggesting that with more motivations come more, perhaps conflicting, expectations.

\section{Advisor or Mentor?}

Before describing our study design and results, we also discuss our choice to use the term "research advisor," instead of the more common term "mentor." Much of the available literature uses the term "mentor" to refer to those individuals who work with undergraduate researchers. However, "mentor" is not always an appropriate term. Kram (1985) identified two functions of mentors: providing career support and providing psychosocial support. In fact, being a research mentor may involve an even greater variety of functions, including advisor, supporter, tutor, master, sponsor, or model of identity (Guberman et al., 2006). In practice, these functions may be variously filled by different individuals (e.g., Windham et al., 2004; Pandya et al., 2007). A recent literature review identified 10 evidence-based practices of high-quality mentoring in undergraduate research, which included technical or expertise functions such as skill training, careful project management, and career development, as well as interpersonal functions such as building community, providing emotional support, and showing personal interest in students (Shanahan et al., 2015). Yet not all research advisors follow all of these exemplary mentoring practices or fill all of these mentoring functions (De Welde and Laursen, 2008; Linn et al., 2015). This body of literature shows that the term "mentor" generally implies "psychosocial support," or a closeness and trust in a personal relationship that is not always present in research advisor-undergraduate researcher interactions.
The term "mentor" may also imply experience and expertise. Indeed, many past studies on mentoring have focused only on faculty members as research mentors. However, at research universities, graduate students, postdoctoral researchers, and other scientists also serve as advisors to undergraduate researchers (Dolan and Johnson, 2009). These people importantly expand the capacity for labs to take on undergraduates, and their experience as research advisors may be formative in preparing them for future mentoring and supervisory roles in academic and industry settings. Only a few studies about research mentoring have included graduate students and postdoctoral researchers in their samples (e.g., Dolan and Johnson, 2009; Prunuske et al., 2013).

For these reasons, we use the term "research advisor" throughout this paper instead of the more common "mentor." This term applies to all individuals who engage with undergraduate researchers, including faculty, graduate students, postdocs, and technicians, who guide and train undergraduate research students, while not assuming a depth of relationship that may or may not be present. This approach is consistent with other authors' views that not all advising is mentoring and that more work is needed to understand the role of individual identities and the relational aspects of undergraduate research advising (Palmer et al., 2015).

\section{METHODS}

\section{Context for the Study}

In this study, we draw upon interview data from advisors in one undergraduate research program at a large, $\mathrm{PhD}$-granting research university in the Western United States. In the program, students worked with advisors to develop a research proposal. Students accepted into the program were then placed in the labs of those advisors and supported through small grants to fund their research experiences. The program supported both summer and academic-year research opportunities. While the content and scope of students' research experiences varied depending on the labs they were in and the projects they were working on, all students in the program attended a few seminars together in order to develop commonly needed skills. For example, students attended a seminar to learn how to prepare a research poster and then another later seminar to help critique one another's posters before presenting them at the endof-program poster session.

\section{Participants and Data Collection}

Data were collected through retrospective interviews with research advisors. All advisors had supervised undergraduates during summer or academic-year research as part of the same program. We had previously conducted interviews with students in the program (Thiry and Laursen, 2011) and then designed the current study to learn more about those students' activities and scientific development from the perspective of their research advisors. Due to a gap in funding, advisors were interviewed approximately 2 years after they had participated in the program, though some advisors had continued to work with other undergraduate researchers.

Each student in the program may have worked with multiple individuals in a lab, but only one was identified as the advisor of record. The sponsoring program provided us lists of these advisors of record, and we drew a stratified sample in 
terms of discipline, gender, and years of experience. Invitations were sent to 52 research advisors. Thirty (58\%) participated in individual interviews and were included in our sample. In total, 21 separate research labs were represented in our sample. We interviewed more than one advisor from seven of these labs because there were multiple student/advisor pairs in those labs.

Of the 30 advisors interviewed, $50 \%(n=15)$ were men and $50 \%(n=15)$ were women. Most research advisors were graduate students $(n=13,43 \%)$ or faculty $(n=11,37 \%)$. Postdoctoral researchers $(n=5,17 \%)$ and one technician made up the remainder. Some were working with their first undergraduate and some had been doing so for more than 40 years. We classified those with less than 5 years experience as "early-career" advisors ( $n=17,57 \%$ of the sample), which included all graduate students, the technician, and some of the postdoctoral researchers. Advisors with five or more years of experience advising undergraduate researchers were classified as "experienced." This group $(n=13,43 \%)$ included all faculty members and some of the postdoctoral researchers. Advisors were all from different departments throughout the life sciences. We do not break out participants by department or other demographic variables in this paper, as small group sizes may make individual identification possible.

The interviews were semistructured so that participants could share their own insights and reflections as well as respond to questions posed by researchers. The order of questions was not the same in every interview. Some topics arose spontaneously, and some were not represented in every interview. For example, the interview protocol did not directly address advisors' motivations to work with undergraduates. However, this topic arose in almost every interview ( 28 of $30,93 \%$ ), signaling the importance of motivation to research advisors.

The interview protocol covered a broad range of topics to help advisors reflect on their undergraduates' research experiences, including their prior research advisor experiences and training, the nature of their students' research work, student gains from research, descriptions of lab interactions, and the costs and benefits of advising undergraduate research. (The full protocol is available in the Supplemental Material.) References to both instructor and student gains are self-reported gains described in comments during interviews; they are not derived from external, standardized measurements. Before any data collection, all interview protocols were reviewed and approved by our Institutional Review Board at the University of Colorado-Boulder. The interviews were audio-recorded, and then transcribed verbatim and entered into NVivo v. 9 (QSR International, 2010).

\section{Data Analysis}

Our general approach to analysis was observational in nature, treating the interviews as revealing motivations as they occurred in a real-world setting. Rather than testing a hypothesis about advisor motivations or aiming to confirm a preexisting theory, we took note of themes that emerged as we analyzed the interview data. During the analysis, sections of transcripts that related to specific topics were assigned codes to identify those topics. For passages of the transcript that addressed multiple topics, we assigned multiple codes. Additionally, codes were used multiple times throughout a transcript if the topic came up multiple times. We started with a coding scheme developed by the second and third authors from their previous work with undergraduate researchers (Laursen et al., 2010, 2012; Thiry et al., 2012). Before beginning, all three authors discussed the existing coding scheme for student interviews. Coding of the advisor interviews was then conducted by the first author and spot-checked by the second and third authors. Consistent with the goal of this exploratory study, we used the process of constant comparative coding (Glaser, 1965) to reveal emergent themes from the interview data. That is, with each interview, we compared the data with our existing codes. New insights sometimes warranted the development of new or more specific codes (e.g., "advisor motivations"), which were then reapplied to earlier coded interviews. Discrepancies were resolved and new codes were developed through consultations among all three authors. If groups of codes shared similar themes, they were organized into domains (Spradley, 1980).

We report results as both the number of interview participants who mentioned a topic ("number of advisors") and the number of comments they made about that topic ("number of comments"). Comparisons of the relative frequencies of specific codes give an estimate of the relative importance of the topics to the participants. These frequencies are not a generalizable or statistical measure.

\section{RESULTS}

In this analysis, we focus on advisors' comments on a range of topics, including their motivations for engaging in research advising, the costs and benefits of doing so, and the benefits they thought students gained by doing undergraduate research. Advisors' motivations help to shed light on why they chose to work with undergraduate researchers, and what their expectations may have been. We compare these expectations with the reported outcomes in terms of perceived costs and benefits, as alignment between expectations and reality may influence advisor retention. Finally, we analyze how advisors' motivations may influence how they work with undergraduate researchers, and how that may affect student outcomes.

\section{Motivations: Why Do Advisors Engage in Advising Undergraduate Researchers?}

During the interviews, many participants spoke about why they chose to advise undergraduate researchers. First, we identified the different types of "advisor motivations." Upon review of the entire set of coded motivations, two distinct categories emerged. We categorized them as "intrinsic" and "instrumental." Intrinsic motivations are those that can only be achieved through the activity of undergraduate research advising, whereas instrumental motivations can also be achieved in other ways. For example, the intrinsic motivation of wanting to be a mentor for undergraduates is only possible through mentoring undergraduates, while it is possible to be productive, an instrumental motivation, through other means.

Advisors made many comments about intrinsic motivations (20 advisors, 41 comments), and most of these were about how advising undergraduates is essential to the development of the scientific workforce (18 advisors, 31 comments). For example, one advisor stated, "Training the undergrads and the grad students is part of my duty. People trained me, so I will do it too" (Male faculty advisor, \#14). The motivation, fulfilling a "duty" 
TABLE 1. Reported advisor motivations for supervising undergraduate researchers

\begin{tabular}{|c|c|c|c|}
\hline $\begin{array}{l}\text { Intrinsic } \\
\text { category }\end{array}$ & Example & $\begin{array}{c}\text { Instrumental } \\
\text { category }\end{array}$ & Example \\
\hline $\begin{array}{l}\text { Development of the } \\
\text { scientific work- } \\
\text { force (18 advisors, } \\
31 \text { comments) }\end{array}$ & $\begin{array}{l}\text { Education is important ... I feel strongly } \\
\text { about being part of a university } \\
\text { community.... I think it's an important } \\
\text { contribution.-Female postdoc, \#22 }\end{array}$ & $\begin{array}{l}\text { Increased lab } \\
\text { productivity } \\
\text { (11 advisors, } \\
18 \text { comments) }\end{array}$ & $\begin{array}{l}\text { The most important thing is that they just get } \\
\text { experiments done, or they help. It's a lot of } \\
\text { the labor that no one wants to do.-Male } \\
\text { faculty, \#13 }\end{array}$ \\
\hline $\begin{array}{l}\text { Wanting to serve as a } \\
\text { mentor ( } 7 \\
\text { advisors, } 9 \\
\text { comments) }\end{array}$ & $\begin{array}{l}\text { I was really excited to start mentoring an } \\
\text { undergraduate because I really enjoy it } \\
\ldots \text { helping them learn all these different } \\
\text { aspects.-Female graduate student, \#7 }\end{array}$ & $\begin{array}{l}\text { Requirement of PI } \\
\text { (6 advisors, } \\
8 \text { comments) }\end{array}$ & $\begin{array}{l}\text { [My PI] basically will assign like grad students } \\
\text { in the lab to mentor them.-Male graduate } \\
\text { student, } \# 24\end{array}$ \\
\hline \multirow{2}{*}{$\begin{array}{l}\text { Undergraduates make } \\
\text { lab work more fun } \\
\text { (1 advisor, } 1 \\
\text { comment) }\end{array}$} & $\begin{array}{l}\text { It's fun.... You need that.... You can't be } \\
\text { just } 9 \text { to } 5 \text { talking about mutations. } \\
\text {-Female faculty, \#21 }\end{array}$ & $\begin{array}{l}\text { Requirement of job or } \\
\text { position ( } 3 \text { advisors, } \\
3 \text { comments) }\end{array}$ & $\begin{array}{l}\text { In my lab, the technician oversees all of the } \\
\text { undergraduate researchers, so it was part of } \\
\text { my job.-Female technician, \#26 }\end{array}$ \\
\hline & & $\begin{array}{l}\text { Helps check work } \\
\text { ( } 1 \text { advisor, } \\
1 \text { comment) }\end{array}$ & $\begin{array}{l}\text { I had a massive amount of things that needed to } \\
\text { be checked again.... She can learn and help } \\
\text { [me] out by checking [my] own work. } \\
\text { - Male graduate student, \#4 }\end{array}$ \\
\hline
\end{tabular}

to train future research scientists, is inherent in the activity of training undergraduate researchers. Most other intrinsic motivations addressed wanting to serve as a mentor (7 advisors, 9 comments), and one participant included undergraduates in her lab because their approach to lab work, which can get "frustrating and boring," helped to "increase the fun ratio" (Female faculty advisor, \#21).

Other motivations were more instrumental (16 advisors, 30 comments) in nature. That is, they were externally directed or served as a means to an end outside of research advising. These included increased lab productivity (11 advisors, 18 comments), requirement of the principal investigator (PI) of the lab ( 6 advisors, 8 comments), and requirement of the individual's specific job or position (3 advisors, 3 comments). While these requirements might also be seen as "duties," we classified them as instrumental, because the goal, such as satisfying one's PI, can also be achieved in ways other than supervising undergraduate researchers. Examples of both types of motivation comments are presented in Table 1.

In addition to the individually coded intrinsic and instrumental motivations, we also classified each interview holistically, based on the main themes in each interviewee's comments about motivations. While most advisors expressed both, five advisors described only instrumental motivations such as external requirements or increased productivity; these were classified as "instrumentally motivated" to supervise undergraduate researchers. Of the remaining advisors, 23 were classified as "intrinsically motivated" to supervise undergraduate researchers. While many of these mentioned increased productivity, they also described intrinsic motivations like wanting to help students, wanting to "pay back" the scientific community by mentoring others as they had themselves been mentored, and enjoying mentoring. No advisors expressed solely intrinsic motivations. Two advisors did not comment on their motivations for advising and were not classified.

We compared each advisor's career stage, expressed in years of advising undergraduate researchers, with his or her motivation for engaging in undergraduate research. Results are presented in Table 2. About a third of early-career advisors were classified as instrumentally motivated. No experienced advisors were classified as instrumentally motivated.

\section{Benefits: What Do Advisors Gain from Advising Undergraduate Researchers?}

In addition to motivations (why the advisors worked with undergraduate researchers), we also coded for advisor benefits: the positive outcomes they reported experiencing through serving as undergraduate research advisors. The two are related, yet distinct. When advisors talked about expected benefits they hoped to achieve by working with undergraduate researchers, we considered those as motivations. However, because interviews were conducted after the conclusion of the undergraduate research program, we coded as benefits only those outcomes advisors reported actually experiencing. The same topic was coded as both a motivation and a benefit only if the outcome was both expected and realized. For example, an advisor may have been motivated by the enjoyment of working with undergraduates, but enjoyment would only also be coded as a benefit if the advisor reported actually enjoying the experience.

The benefits also fit into the same two categories as motivations, instrumental and intrinsic. Intrinsic benefits are those inherent to the activity of supervising undergraduate researchers. Because they are inherent to working together with undergraduate researchers, there are often mutual benefits for both advisors and students. When comments were about benefits that could be gained in ways other than working with undergraduate researchers, we classified them as instrumental.

TABLE 2. Research advisor experience level and holistic classification of advisor's motivations for supervising undergraduate researchers

\begin{tabular}{lccc}
\hline Career stage & $\begin{array}{c}\text { Intrinsic } \\
\text { motivation }\end{array}$ & $\begin{array}{c}\text { Instrumental } \\
\text { motivation }\end{array}$ & Unassigned \\
\hline Early career & 11 & 5 & 1 \\
Experienced & 12 & 0 & 1 \\
\hline
\end{tabular}


TABLE 3. Reported benefits of supervising undergraduate researchers

\begin{tabular}{|c|c|}
\hline Category & Example \\
\hline & Intrinsic \\
\hline $\begin{array}{l}\text { nproved teaching and mentoring skills } \\
\text { ( } 22 \text { advisors, } 49 \text { comments) }\end{array}$ & $\begin{array}{l}\text { [Data got messed up because] I didn't come talk to her. We didn't have a weekly } \\
\text { meeting.... As an undergrad, there isn't necessarily that [ability to do it yourself] ... } \\
\text { The professor and I agreed that it was our responsibility to make sure we were more } \\
\text { involved with the project.-Female postdoc, } \# 12\end{array}$ \\
\hline $\begin{array}{l}\text { Personal rewards (i.e., friendship, feeling of doing } \\
\text { something good) ( } 22 \text { advisors, } 30 \text { comments) }\end{array}$ & $\begin{array}{l}\text { My career goal is to actually work at a primarily undergraduate institution so that I can work } \\
\text { with undergrads, because I do find it to be one of the most rewarding parts of my } \\
\text { research-Female graduate student, } \# 16\end{array}$ \\
\hline $\begin{array}{l}\text { Deeper understanding of scientific concepts for } \\
\text { advisor through teaching undergraduates } \\
\text { (16 advisors, } 23 \text { comments) }\end{array}$ & $\begin{array}{l}\text { He constantly raised my game.... Working with these bright young people, they ask } \\
\text { questions that constantly keep you on your toes.-Male postdoc, \#23 }\end{array}$ \\
\hline $\begin{array}{l}\text { Contributions to preparing future scientists } \\
\text { (14 advisors, } 19 \text { comments) }\end{array}$ & $\begin{array}{l}\text { It's like [we] had a hand in training these people. Maybe they'll come back [here], maybe } \\
\text { not, but either way, they have their own experience [here] that they can say was a major } \\
\text { impetus for them going on in science.-Female faculty, \#8 }\end{array}$ \\
\hline \multirow[t]{2}{*}{$\begin{array}{l}\text { Increased energy and enthusiasm in the lab group } \\
\text { (11 advisors, } 12 \text { comments) }\end{array}$} & $\begin{array}{l}\text { They bring a fresh and fun perspective.... It's just really, really fun, and I really, really enjoy } \\
\text { that enthusiasm.- Female faculty, \#6 }\end{array}$ \\
\hline & Instrumental \\
\hline Increased productivity (20 advisors, 31 comments) & I like to have undergrads. One good undergrad can get you a paper-—Male faculty, \#14 \\
\hline $\begin{array}{l}\text { Career preparation for advisor (résumé building } \\
\text { and mentoring experience) ( } 22 \text { advisors, } 29 \\
\text { comments) }\end{array}$ & $\begin{array}{l}\text { It definitely helps to be able to explain what you're doing.... I'll have people who will work } \\
\text { for me [in the future]. Being able to explain to people is always a good communication } \\
\text { skill.-Female graduate student, } \# 1\end{array}$ \\
\hline $\begin{array}{l}\text { Long-term benefits to the research group through } \\
\text { students who continue with the same lab for } \\
\text { graduate school or career (10 advisors, } \\
15 \text { comments) }\end{array}$ & $\begin{array}{l}\text { Many of the undergrads that are going through our program want to go to graduate } \\
\text { school.... All of my new graduate students in the fall have done undergraduate research } \\
\text { in our labs.-Male faculty, } \# 3\end{array}$ \\
\hline $\begin{array}{l}\text { Prestige for the university or lab (7 advisors, } \\
7 \text { comments) }\end{array}$ & $\begin{array}{l}\text { We had a couple of students go out to [an undergraduate research conference] and when } \\
\text { they present well, it looks really well [for] the program.--Male postdoc, \#18 }\end{array}$ \\
\hline $\begin{array}{l}\text { Help in recruiting future students ( } 3 \text { advisors, } \\
5 \text { comments) }\end{array}$ & $\begin{array}{l}\text { Undergraduate research is an opportunity that plays a big role in this environment, and } \\
\text { [it's] not available in other college environments.-Male faculty, \#3 }\end{array}$ \\
\hline
\end{tabular}

Because these are not inherent to working together with students, they are often about how a student worked for, and served as a means to, the advisor's benefit. The benefits advisors mentioned are included in Table 3.

While all advisors described benefits that they received, advisors with intrinsic motivations tended to discuss mutual benefits for themselves that co-occurred with those for their students. They also tended to discuss richer, layered views of the multiple benefits of undergraduate research. For example, one faculty member described how research advising helped all researchers in the faculty-graduate student-undergraduate triad common at graduate institutions (Dolan and Johnson, 2009); he described both increased productivity and deeper understanding of the scientific concepts:

One is the obvious: [the graduate students] get helped. The other is, it's very easy to forget that you, [faculty], were in that state at one point. I think you learn so much more by teaching than you do even by doing. I think it's really good for the graduate students to be explaining things to the undergraduates and so forth, because they suddenly realize, just like [faculty] do when we're teaching, that "I don't really understand this."-Male faculty advisor, \#10

On the other hand, advisors with mainly instrumental motivations tended to focus solely on their own benefit of increased productivity and described the student as a means to that end, as in this example:

All of them are working on portions of my dissertation, which it clearly is beneficial. Even though it takes time to train them, in the big scheme of things, [on] large tasks, the hours they put in are crucial. They save me a lot of time and help with general productivity in the lab.... We get a lot out of having undergrads - if we didn't, then we wouldn't have them.-Male graduate student advisor, \#15

Because we classified motivations separately from benefits and classified advisors holistically based on their expressed motivations for supervising undergraduate researchers, we are able to assess this alignment by directly comparing their motivations with the benefits they reported. Results are presented in Table 4. On average, advisors with intrinsic motivations made roughly twice as many comments about intrinsic benefits as they did about instrumental benefits. Advisors with instrumental motivations made about the same number of comments about intrinsic benefits as they did about instrumental benefits. These relative frequencies may give an indication of the relative importance of those topics for advisors. Upon comparison, both groups reported roughly equivalent total benefits, but intrinsically motivated advisors tended to report more intrinsic benefits and slightly fewer instrumental benefits. This suggests that 
TABLE 4. Advisor benefits reported by holistic classification of advisor's motivations for supervising undergraduate researchers

\begin{tabular}{llll}
\hline & \multicolumn{3}{c}{ Advisors } \\
\cline { 2 - 4 } Advisor & \multicolumn{1}{c}{$\begin{array}{c}\text { Intrinsically } \\
\text { motivated } \\
\text { benefits }\end{array}$} & $\begin{array}{c}\text { Instrumentally } \\
\text { motivated } \\
(\boldsymbol{n}=\mathbf{2 3})\end{array}$ & $\begin{array}{c}\text { Unassigned } \\
(\boldsymbol{n}=\mathbf{2})\end{array}$ \\
\hline Intrinsic & 73 comments & 11 comments & 12 comments \\
& 3.2 per advisor & 2.2 per advisor & 6 per advisor \\
Instrumental & 41 comments & 11 comments & 6 comments \\
& 1.8 per advisor & 2.2 per advisor & 3 per advisor \\
\hline
\end{tabular}

advisors may be more alert to benefits that match their initial motivations.

\section{Practices: How Do Motivations and Costs/Benefits Shape How Advisors Work with Undergraduate Researchers?} Research advisors had different motivations for working with undergraduate researchers and experienced benefits that tended to match their motivations. These differences in motivations may also have influenced their expectations about the outcomes research experiences could provide for students. Prior research has shown links between advisor preparation and expectations, the way they work with students, and student outcomes (Pfund et al., 2006). To explore this link between advisor motivations and perceived student outcomes, we classified advisor comments about student gains from research using six categories established in previous studies (Laursen et al., 2010), including the following:

1. thinking and working like a scientist: intellectual gains in application of scientific knowledge and skills, understanding the process of research, and increased disciplinary knowledge;

2. becoming a scientist: behaviors and attitudes necessary to become a scientist;

3. personal/professional gains: confidence and comfort with ability to do well in scientific pursuits;

4. skills: lab, field, and communication skills essential to research scientists;

5. clarification of educational and career aspirations; and

6. enhanced career and graduate school preparation.

Overall, advisors with intrinsic motivations observed slightly more student benefits (19.4 comments per interview) than did advisors with instrumental motivations (16.0 comments per interview). This trend held separately for most of the six cate- gories as well, as shown in Table 5. The student benefits that advisors noted may shed some light on how they worked with undergraduate students: instrumentally motivated advisors tended to describe instrumental student benefits of undergraduate research experience. In the following example, the advisor described research experiences as a one-way ticket to graduate school, rather than as a space for exploring one option out of a variety of career possibilities:

There is always the self-recruitment for academic types, once you're in that setting. But I think all these people also knew that doing just chemistry, or biology, with just a bachelor's degree doesn't get you far.... The mentality inside the lab [is] to keep going to school, and to keep bettering yourself.-Male graduate student advisor, \#4

Here, the advisor focuses on a goal (i.e., graduate school admission) that is not necessarily inherent in the research experience itself. On the other hand, Laursen et al. (2010) found that some students used undergraduate research experiences as a chance to determine their own interest in and suitability for a career as a research scientist; the goal (i.e., experiencing research) was inherent in the activity itself.

Interestingly, of the four instrumentally motivated advisors (out of five total) who commented on career clarification, two compared their students' experiences with their own experiences deciding on a future career path in academia. These advisors were both early in their careers, so these decisions were more recent for them. In contrast, advisors with intrinsic motivations spoke about career clarification more broadly, acknowledging that research experience is not just preparation for graduate school, and that, for some students, it does the opposite by making it clear that a career in scientific research is not actually what they want.

In addition to differences in the student benefits emphasized, differences in advisor motivations may also have influenced how they worked with students. Many advisors commented on how they selected projects for students. Advisors with instrumental motivations tended to involve undergraduates on aspects of their projects that served to help the advisor. This usually meant carrying out predesigned data-collection procedures and, in some cases, replicating studies that had already been done. For example, one instrumentally motivated advisor explained how he selected a project where the student worked mainly on data collection to verify work he had already done himself:

TABLE 5. Student gains reported by advisors by holistic classification of advisor's motivations for supervising undergraduate researchers

\begin{tabular}{lcc}
\hline & \multicolumn{2}{c}{ Average number of comments per advisor interview } \\
\cline { 2 - 3 } Category & $\begin{array}{c}\text { Intrinsically motivated advisors } \\
(\boldsymbol{n}=\mathbf{2 3})\end{array}$ & $\begin{array}{c}\text { Instrumentally motivated advisors } \\
(\boldsymbol{n}=\mathbf{5})\end{array}$ \\
\hline Thinking and working like a scientist (intellectual gains) & 5.4 & 4.2 \\
Enhanced career preparation & 4.3 & 3.6 \\
Becoming a scientist & 3.8 & 3.6 \\
Skills & 2.1 & 1.0 \\
Career clarification & 2.0 & 2.4 \\
Personal/professional gains & 1.7 & 1.2 \\
\hline
\end{tabular}


I had a massive amount of things that needed to be checked again, and it was a good opportunity to do the scientific process and get familiar with the instruments.... So it was kind of like she can learn and help [me] out by checking [my] own work.... It was something I was very familiar with, which is good, I think, [when] mentoring someone on something. [Mentoring on] something that you're not familiar with is a disaster.-Male graduate student advisor, \#5

On the other hand, advisors with intrinsic motivations tended to focus on how the student would benefit from the particular project, rather than how it would benefit the advisor. For example, one advisor noted how he specifically picked projects that were good learning opportunities for students but not central to his own research agenda, or, in his words, "a project that I would like to get to work but isn't very high priority, and something I could give [the student] direction for but not necessarily count on having it work" (Male graduate student, \#24).

While many intrinsically motivated advisors did select projects that involved mastering routine lab skills or replicating known results, these advisors also included more broad and authentic scientific work in the projects they picked for students. Some authors define "authentic scientific work" by its product-answering novel questions to make new scientific discoveries. However, in this context, we use the more broadly held definition based on engaging students in the processes of authentic scientific work such as forming hypotheses, designing studies, and collecting and analyzing data about questions that are novel to the students but not necessarily the entire scientific community (Spell et al., 2014). (For an in-depth discussion of the definition of "authenticity," see Rowland et al., 2016.) One advisor explained, "They understand why the experiment was done.... They get to work on [experimental design]. They get the whole picture of how science is done" (Male faculty advisor, \#10). Another intrinsically motivated faculty advisor described offering two different tracks:

One track is if they basically want to help out in the lab, and usually what they wind up doing in that case, is on the lab side of things, like routine [lab procedures]. On the computational side, it's typically something like ... implementation of a particular mathematical routine [that's] in a recently published paper and that kind of thing. The other track [is] if they want to do a larger scale [and time] load project like an honors thesis project or an independent study.... So in that case what makes it successful is that this project ... can be completed in the time available, so it's got to be reasonable. And then additionally there has to be one specific postdoc or grad student from the lab who is excited [to] let that student on that project, because otherwise it's very easy for the students to drift or go in unproductive directions.-Male faculty advisor, \#27

Other intrinsically motivated advisors also described picking projects like this speaker's "second track"-broader projects that accommodated students' individual interests and that would help students develop as scientists, again focusing on helping students learn rather than solely advancing the advisor's own research. One advisor described doing this by increasing the scope of a project over time and by including undergraduates in lab activities beyond routine data collection:
I will typically assign those entry-level students to a graduate student who can get them doing something that will help them in, I don't want to say the word menial, but something that, if it backfires, it's not going to set us back too much. So, sort of a low-risk, but hopefully a fun, first way to get engaged.... The other thing is that I will make sure that everybody comes to our weekly lab meetings, during which a grad student, or myself, or postdocs, will present, or even undergrads will present research, or talk about a paper. I like to give them the flavor of things.... Then, if they're super gung-ho, maybe the semester following that, I'll ask for an independent study.Female faculty advisor, \#6

In general, instrumentally motivated advisors tended to pick projects emphasizing data collection through replicating known studies or procedures. Student work on such projects largely focused on developing skills in data collection and lab techniques. Intrinsically motivated advisors tended to pick projects with a larger scope, and some involved students in all stages of the scientific process, including the design, analysis, and reporting of results, in addition to data collection.

\section{DISCUSSION}

Our results reveal some interesting findings about advisor motivations. Two different kinds of motivations, instrumental and intrinsic, shaped advisors' choices to work with undergraduate researchers. Moreover, it seems that there is a relationship between types of motivations and career stage, as the small number of advisors who only expressed instrumental motivations were all early in their careers. The rest of the advisors, across various career stages, expressed a blend of intrinsic and instrumental motivations. When considering the interviews holistically, these advisors' intrinsic motivations seemed stronger than their instrumental motivations, so we classified them as intrinsically motivated.

No advisors in this sample expressed only intrinsic motivations. Because expected benefits can also be motivations, this may just be the nature of research advising: all advisors may expect that adding another person to a research lab most likely will increase productivity. In this exploratory interview study, we did not have a way to measure the strengths of the motivations. So, we cannot tell whether increased productivity was just a benefit most advisors knew they would likely experience or a motivation that caused them to participate. This is analogous to a career choice in which the work is intrinsically motivating, but we still expect that it will help to pay the bills. Given the research on mixed motivations and how they relate to longterm outcomes, experimental work is needed in order to systematically test the relative strengths of different motivations.

The advisors in our study have reported motivations that differ from those in the existing literature. Morales et al.'s (2016) model includes various demographic and situational factors, yet only includes one dispositional factor, which they termed "organizational citizenship behavior." These researchers considered three types of organizational citizenship behavior: 1) increasing diversity through mentorship of underrepresented minority students, 2) enjoyment of teaching students about research, and 3) being able to help prepare students for graduate studies. For our sample, advisors' dispositional factors were different from those assessed by Morales and colleagues. In particular, the advisors in our study did not talk about 
minority groups specifically when they commented on motivations to develop the scientific workforce.

Morales and colleagues did not find a link between teaching or graduate preparation and participation in undergraduate research, yet both topics emerged from our interviews. Although "I enjoy teaching students about research" was not linked with serving as a research advisor in their results, seven of our advisors $(23 \%)$ reported that they enjoyed mentoring and the desire to serve as a mentor was a motivating factor for them. Similarly, their third item, "I am able to help students be better prepared for graduate studies," was also not found to correlate with participation in undergraduate research. However, in our study, developing the scientific workforce was the most frequently mentioned motivation. This difference may be partially related to the wording of their survey item, as some respondents may have interpreted the phrase, "I am able," as a situational factor (i.e., access) or as a measure of success rather than a dispositional factor.

Our qualitative study also found some additional instrumental motivations not included in Morales and colleagues' model: PIs' requirements of senior lab members to advise undergraduates as part of their laboratory duties. These requirements were particularly salient for graduate students who served as advisors. Although graduate students often work closely with undergraduate researchers, few studies have included graduate students in their samples of research advisors. Indeed, Morales et al. (2016) tested their model using a survey of only faculty members. Dolan and Johnson (2009), in one of only two other studies about motivation that include graduate students, found that "graduate/postdoctoral students ... primarily saw mentoring undergraduates as a means to two ends: improving their research productivity and meeting the implicit or explicit expectations of the research group" (p. 491). That study included seven graduate and postdoctoral students from a single research group, so it is limited in its generalizability. Our study includes 30 advisors in 21 different research groups, with faculty members in addition to graduate and postdoctoral students. Together, these two studies suggest that early-career scientists have motivations for supervising undergraduates that tend to be more instrumental than those of experienced faculty.

As we have shown, these differences in advisor motivations for supervising undergraduate researchers may shape the way advisors work with students. Instrumental motivations may lead advisors to select projects that focus more on producing data and in the process help develop students as technicians, leading to gains for students in areas such as lab skills and data-collection techniques. Advisors with intrinsic motivations, on the other hand, focused more on developing students as research scientists by engaging them throughout the entire process of scientific inquiry. Other research has found that faculty advisors engaged undergraduates in more high-level activities such as exploring and articulating learning, while graduate student advisors tended to focus on the technical aspects of research (Feldman et al., 2013). Given the relationships in our data, it seems that differences in types of motivation may be a moderating or mediating factor between career stage and how advisors work with undergraduates.

If there is a relationship between motivations and career stage, what explains it? We suggest two possible explanations: 1) motivations may be static for individuals, and advisors with primarily instrumental motivations may stop advising later in their careers, once they have the ability to decide for themselves; or 2) motivations may be dynamic, and intrinsic motivations may develop over time for some individuals. Owing to the cross-sectional nature of our interview data, we cannot track changes in motivation over time, but there is some evidence about this, primarily from retrospective remarks in the interviews.

In particular, some of the evidence from our interviews suggests that advisors with instrumental motivations only engage in research advising early in their careers when they are required to do so by more senior colleagues, but then stop advising once they gain more autonomy. Twelve advisors reported being required to supervise undergraduate researchers. Only one of these was an experienced advisor, and he was required to supervise more students than he felt he had time for as a postdoc. No other experienced advisors mentioned being required to advise undergraduates, while 11 of the 17 earlycareer advisors (65\%) did.

Other research supports the idea that advisors with instrumental motivations may stop advising as their careers advance. Our instrumentally motivated advisors were driven largely by increased productivity and also focused on it more as a benefit. However, undergraduate research has been described as posing a "fundamental tension" between producing research results and helping students learn and develop, which often occurs through cycles of trial, error, and retrial (Laursen et al., 2012). Motivations driven mainly by increased productivity may cause these advisors to be less tolerant of the slow pace at which undergraduates learn and develop. Therefore, they may see fewer benefits and fewer reasons to continue advising students as their careers advance.

However, it may also be that intrinsic motivations develop over time and layer onto initial instrumental motivations as advisors gain experience and a deeper understanding of advising. There is evidence to support this, too, as intrinsically motivated advisors still expressed some instrumental motivations. Indeed, some advisors' comments describe how their intrinsic motivations developed over time:

It's closer to home, in terms of mentoring the next generation of scientists.... This is not something that I felt strongly about initially, when I was younger. It's something that gradually develops as I age, and now at this stage of my career, I think it's so important to try to keep the pipeline going, and maintain that flow of the young scientists.-Female faculty advisor, \#17

As advisors gain more experience and reflect back on their career paths, they may develop more intrinsic motivations, especially the desire to "pay it forward" and shape young students in the same way that mentors had shaped their own careers.

For intrinsically motivated advisors, advising meant working with students beyond just equipping them with lab skills. They described research experiences as a chance for a student to explore whether or not a career in scientific research is actually what he or she wants. By contrast, the instrumentally motivated early-career advisors described research experience as a one-way ticket to graduate school. Many commented on how 
research experiences had helped them advance their own careers in scientific research. This may indicate that early-career advisors have yet to develop a broad understanding of advising beyond their own experiences, and do not yet see all the multifaceted benefits of undergraduate research that intrinsically motivated advisors reported.

Experience is not necessarily the only source for intrinsic motivations, though, as most early-career advisors (11 of 17, $65 \%$ ) were classified as intrinsically motivated. Some individuals may already have intrinsic motivations before becoming advisors, and such motivations may develop more quickly for some advisors than others. Future longitudinal research should explore how advisor motivations evolve throughout their careers.

Our findings suggest that instrumentally motivated advisors tend to focus on advancing their own research, whereas intrinsically motivated advisors are aware of the "fundamental tension" between student learning and research productivity and work to find a balance that benefits both students and themselves. By involving students in discovery and working to achieve a broader range of educational outcomes, intrinsically motivated advisors may in fact be more effective in helping students succeed and advance in the profession (Russell et al., 2007). Future research should explore more deeply how advisors' motivations affect student gains from undergraduate research, their long-term pursuit of advanced degrees, and entry into STEM careers.

Earlier, we discussed our reasons for using the term "research advisor" rather than "mentor." The evidence presented here suggests that not all advisors engage in all of the functions of a mentor. Instrumentally motivated advisors tended to discuss only a few of the functions of mentoring and mostly focused on technical training. On the other hand, intrinsically motivated advisors engaged in more of the functions of mentors, including interpersonal functions like providing emotional support or friendship and taking a personal interest in students by tailoring projects to their needs. Therefore, using the term "mentor" may assume certain functions or a close relationship that is not always present and may obscure differences in motivations that have consequences for what students gain from research experiences.

Undergraduate research experiences can be powerful in bringing about positive outcomes for students, and improving access to these experiences is a commonly recommended strategy for improving undergraduate education. To achieve this, we cannot assume that all advisors want to fulfill all of the roles associated with mentors. We should take into account advisor motivations and whether or not they shift over time. If advisor motivations are static, and instrumentally motivated advisors just stop working with undergraduates as their careers progress, efforts to improve student outcomes and access to research experiences should focus on making sure the right kind of people are hired and retained to provide high-quality research advising to undergraduate students.

However, if motivations develop over time, the focus should be on creating structures and programs that help research scientists to develop these intrinsic motivations and learn how to involve undergraduates in research in ways that support students' learning and pursuit of scientific interests. Various practices have been suggested for how best to do this (e.g., Johnson et al., 2015), but they are often externally directed strategies such as removing obstacles or creating incentives for advisors. Research in other fields suggests that creating instrumental motivation through offering external rewards for participation can actually be detrimental to performance and outcomes (Deci and Ryan, 1985). Our findings suggest that the focus should instead be on increasing intrinsic motivations.

For example, one area that could easily be leveraged is advisors' enjoyment of working with undergraduate researchers. Only one advisor reported being motivated by the enjoyment expected from working with students, yet 22 advisors (73\%) reported experiencing personal rewards such as friendship, and 11 advisors (37\%) reported that working with undergraduates had increased the energy and enthusiasm in their labs. Enjoyment seems to be a common, yet less anticipated benefit that could be particularly useful to increase early-career advisors' intrinsic motivations, since they are often close in age to undergraduates and may especially enjoy these near-peer relationships.

It may also be relatively easy for senior colleagues to influence less-experienced colleagues' intrinsic motivations. One graduate student explained that his PI's beliefs shaped his own thoughts about working with students:

Our advisor is also very supportive of undergraduate research. She never says, "You're working with this person," but she'll often say, "Hey, if you have time, I'd really like supporting undergraduate students." That helped me think about it as an idea.-Male graduate student advisor, \#20

If senior colleagues can help junior colleagues develop intrinsic motivations simply by discussing their own intrinsic motivations and rewards, this could be an easy, effective way to get more potential advisors motivated to work with undergraduates.

\section{ACKNOWLEDGMENTS}

The evaluation and research was supported by a grant from the Howard Hughes Medical Initiative (HHMI) through the Biological Sciences Initiative (BSI) at the University of ColoradoBoulder. Any opinions, findings, and conclusions or recommendations expressed in this material are those of the authors and do not necessarily reflect the views of HHMI or the BSI. We thank all of the study participants.

\section{REFERENCES}

Adedokun OA, Dyehouse M, Bessenbacher A, Burgess WD (2010). Exploring faculty perceptions of the benefits and challenges of mentoring undergraduate research. Paper presented at the annual meeting of the American Educational Research Association, held April 30 to May 4, 2010, in Denver, CO. http://eric.ed.gov/?id=ED509729 (accessed 10 November 2015).

Baker VL, Pifer MJ, Lunsford LG, Greer J, Ihas D (2015). Faculty as mentors in undergraduate research, scholarship, and creative work: motivating and inhibiting factors. Mentor Tutor 23, 394-410.

Bangera G, Brownell SE (2014). Course-based undergraduate research experiences can make scientific research more inclusive. CBE Life Sci Educ 13, $602-606$

Boyer Commission on Educating Undergraduates in the Research University (1998). Reinventing Undergraduate Education: A Blueprint for America's Research Universities, Stony Brook: State University of New York at Stony Brook. 
Brownell SE, Tanner K (2012). Barriers to faculty pedagogical change: lack of training, time, incentives, and... tensions with professional identity? CBE Life Sci Educ 11, 339-346.

Corwin-Auchincloss L, Laursen SL, Branchaw JL, Eagan K, Graham M, Hanauer DI, Lawrie G, McLinn CM, Pelaez N, Rowland S, et al. (2014). Assessment of course-based undergraduate research experiences: a meeting report. CBE Life Sci Educ 13, 29-40.

Deci EL, Ryan RM (1985). Intrinsic Motivation and Self-Determination in Human Behavior, New York: Plenum.

De Welde K, Laursen SL (2008). The "ideal type" advisor: how advisors help STEM graduate students find their "scientific feet." Open Educ J 7, 49-61.

Dolan E, Johnson D (2009). Toward a holistic view of undergraduate research experiences: an exploratory study of impact on graduate/postdoctoral mentors. J Sci Educ Technol 18, 487-500

Eagan MK, Hurtado S, Chang MJ, Garcia GA, Herrera FA, Garibay JC (2013). Making a difference in science education: the impact of undergraduate research programs. Am Educ Res Journal 50, 683-713.

Eagan MK, Sharkness J, Hurtado S, Mosqueda CM, Chang MJ (2011). Engaging undergraduates in science research: not just about faculty willingness. Res High Educ 52, 151-177.

Feldman A, Divoll KA, Rogan-Klyve A (2013). Becoming researchers: the participation of undergraduate and graduate students in scientific research groups. Sci Educ 97, 218-243.

Glaser BG (1965). The constant comparative method of qualitative analysis Soc Problems 12, 436-445.

Grant AM, Nurmohamed S, Ashford SJ, Dekas K (2011). The performance implications of ambivalent initiative: the interplay of autonomous and controlled motivations. Organ Behav Hum Decis Process 116, 241-251.

Guberman J, Saks J, Shapiro B, Torchia M (2006). Making the Right Moves: A Practical Guide to Scientific Management for Postdocs and New Faculty, Research Triangle Park, NC/Chevy Chase, MD: Burroughs Welcome Fund/Howard Hughes Medical Institute.

Hayward CN, Thiry H, Laursen SL (2013). Evaluation of the Undergraduate Research Programs of the Biological Sciences Initiative: Advisors' Perspectives, Boulder, CO: Ethnography \& Evaluation Research. www.colorado edu/eer (accessed 4 November 2016).

Johnson WB, Behling LL, Miller P, Vandermaas-Peeler M (2015). Undergraduate research mentoring: obstacles and opportunities. Mentor Tutor 23 441-453.

Kiviniemi MT, Snyder M, Omoto AM (2002). Too many of a good thing? The effects of multiple motivations on stress, cost, fulfillment, and satisfaction. Pers Soc Psychol Bull 28, 732-743.

Kram KE (1985). Mentoring at Work: Developmental Relationships in Organizational Life, Glenview, IL: Scott Foresman.

Laursen SL, Hunter A-B, Seymour E, Thiry H, Melton G (2010). Undergraduate Research in the Sciences: Engaging Students in Real Science, San Francisco: Jossey-Bass.

Laursen SL, Seymour E, Hunter A-B (2012). Learning, teaching and scholarship: fundamental tensions of undergraduate research. Change 44, 30-37.

Linn MC, Palmer E, Baranger A, Gerard E, Stone E (2015). Undergraduate research experiences: impacts and opportunities. Science 347, 1261757.

Lopatto D, Tobias S (2010). Science in Solution: The Impact of Undergraduate Research on Student Learning, Washington, DC: Council on Under graduate Research.

Lunsford L (2012). Doctoral advising or mentoring? Effects on student outcomes. Mentor Tutor 20, 251-270.

Morales DX, Grineski SE, Collins TW (2016). Faculty motivation to mentor students through undergraduate research programs: a study of enabling and constraining factors. Res High Educ, doi:10.1007/s11162-016-9435-x.
National Academies of Sciences, Engineering, and Medicine (2015). Integrating Discovery-Based Research into the Undergraduate Curriculum: Report of a Convocation, Washington, DC: National Academies Press.

National Academy of Sciences, National Academy of Engineering, and Institute of Medicine (2011). Expanding Underrepresented Minority Participation, Washington, DC: National Academies Press.

National Science and Technology Council (2013). Federal Science, Technology, Engineering, and Mathematics (STEM) Education 5-Year Strategic Plan, Washington, DC

Osborn JM, Karukstis KK (2009). The benefits of undergraduate research, scholarship, and creative activity. In: Broadening Participation in Undergraduate Research: Fostering Excellence and Enhancing the Impact, ed. M Boyd and J Wesemann, Washington, DC: Council on Undergraduate Research, 41-53.

Palmer RJ, Hunt AN, Neal M, Wuetherick B (2015). Mentoring, undergraduate research, and identity development: a conceptual review and research agenda. Mentor Tutor 23, 411-426.

Pandya RE, Henderson S, Anthes RA, Johnson RM (2007). BEST practices for broadening participation in the geosciences: strategies from the UCAR Significant Opportunities in Atmospheric Research and Science (SOARS ${ }^{\circledR}$ ) Program. J Geosci Educ 55, 500-506.

Pfund C, Pribbenow CM, Branchaw J, Lauffer SM, Handelsman J (2006). The merits of training mentors. Science 311, 473-474.

Prunuske AJ, Wilson J, Walls M, Clarke B (2013). Experiences of mentors training underrepresented undergraduates in the research laboratory. CBE Life Sci Educ 12, 403-409.

QSR International (2010). NVivo qualitative data analysis software, version 9 www.qsrinternational.com/.

Rowland S, Pedwell R, Lawrie G, Lovie-Toon J, Hung Y (2016). Do we need to design course-based undergraduate research experiences for authenticity? CBE Life Sci Educ 15, ar79.

Russell SH, Hancock MP, McCullough J (2007). Benefits of undergraduate research experiences. Science 316, 548-549.

Ryan RM, Deci EL (2000). Intrinsic and extrinsic motivations: classic definitions and new directions. Contemp Educ Psychol 25, 54-67.

Shanahan JO, Ackley-Holbrook E, Hall E, Stewart K, Walkington H (2015). Ten salient practices of undergraduate research mentors: a review of the literature. Mentor Tutor 23, 359-376.

Spell RM, Guinan JA, Miller KR, Beck CW (2014). Redefining authentic research experiences in introductory biology laboratories and barriers to their implementation. CBE Life Sci Educ 13, 102-110.

Spradley J (1980). Participant Observation, New York: Holt, Rinehart, and Winston.

Thiry H, Laursen SL (2011). The role of student-advisor interactions in apprenticing undergraduate researchers into a scientific community of practice. J Sci Educ Tech 20, 771-784.

Thiry H, Weston TJ, Laursen SL, Hunter A-B (2012). The benefits of multi-year research experiences: Differences in novice and experienced students reported gains from undergraduate research. CBE Life Sci Educ 11, $260-$ 272.

Vallerand RJ, Fortier MS, Guay F (1997). Self-determination and persistence in a real-life setting: toward a motivational model of high school dropout. J Pers Soc Psychol 72, 1161-175.

Webber KL, Laird TFN, BrckaLorenz AM (2013). Student and faculty member engagement in undergraduate research. Res High Educ 54, 227-249.

Windham TL, Stevermer AJ, Anthes RA (2004). SOARS ${ }^{\circledR}$. Bull Am Meteorol Soc 85,42

Wrzesniewski A, Schwartz B, Cong X, Kane M, Omar A, Kolditz T (2014). Multiple types of motives don't multiply the motivation of West Point cadets. Proc Natl Acad Sci USA 111, 10990-10995. 